\title{
Possessing a poor anaerobic capacity does not prevent the diel vertical migration of Nordic krill Meganyctiphanes norvegica into hypoxic waters
}

\author{
John I. Spicer ${ }^{1}$, Maria A. Thomasson ${ }^{2}$, Jarl-Ove Strömberg ${ }^{2, *}$ \\ ${ }^{1}$ Department of Animal \& Plant Sciences, University of Sheffield, Sheffield S10 2TN, United Kingdom \\ ${ }^{2}$ Kristineberg Marine Research Station, Kristineberg 2130, S-45034 Fiskebäckskil, Sweden
}

\begin{abstract}
During their diel vertical migration in the Gullmarsfjord (Swedish west coast) Nordic krill Meganyctiphanes norvegica made excursions into regions of severe hypoxia, $>70 \mathrm{~m}$ depth, during the day. Consequently, we investigated the capacity for anaerobic metabolism by $M$. norvegica and the extent to which they utilize this capacity in the field. L-lactate was the main end-product of anaerobic metabolism. The concentration of L-lactate in the haemolymph ([lactate $]_{\mathrm{HL}}$ ) under conditions of acutely declining $\mathrm{pO}_{2}$ only increased below 4 to $6 \mathrm{kPa}$. During anoxia, no krill survived $>1 \mathrm{~h}$ and accumulation of L-lactate was at its most pronounced. Handling stress had little effect on [lactate $]_{\mathrm{HL}}$. Field observations (January 1998) showed that during the day krill resided at a depth of 65 to $85 \mathrm{~m}\left(\mathrm{pO}_{2}=3\right.$ to $10 \mathrm{kPa}$ ). Net cages were stocked with krill, trawled from 60 to $70 \mathrm{~m}$ depth at dusk, and then kept overnight at 40,70 and $90 \mathrm{~m}$ depth $\left(\mathrm{pO}_{2}>14,6.1\right.$ and $1.8 \mathrm{kPa}$ respectively). This resulted in krill mortality of 7,70 , and $100 \%$ respectively. While individuals caged at $40 \mathrm{~m}$ showed [lactate] $]_{\mathrm{HL}}$ no greater than that of normoxic laboratory individuals $\left(3.04 \pm 1.05 \mathrm{mmol} \mathrm{l}^{-1}\right)$, survivors at $70 \mathrm{~m}$ showed elevated concentrations $\left(9.91 \pm 1.68 \mathrm{mmol} \mathrm{l}^{-1} \text { ). Furthermore, newly trawled krill (at dusk) had [lactate }\right]_{\mathrm{HL}}=7.18$ $\pm 2.72 \mathrm{mmol} \mathrm{l}^{-1}$, indicating that, like the caged individuals at that depth, they too had resorted to anaerobic metabolism. This study has shown that while anaerobic metabolism is not well developed in $M$. norvegica, individuals do enter bodies of water where the $\mathrm{pO}_{2}$ is below that required to maintain aerobic metabolism. Utilization of anaerobiosis seems to be critical to the ability to enter such $\mathrm{O}_{2}$ poor water, although the krill are close to the limits of their physiological capacity at such times.
\end{abstract}

KEY WORDS: Hypoxia Anoxia $\cdot$ Krill $\cdot$ Crustacea $\cdot$ Ecophysiology

\section{INTRODUCTION}

Most of the 86 species of krill (Euphausiacea) are diel migrators, the exceptions being about 12 to 18 mesoand bathypelagic species (Mauchline 1980). Some species exhibit pronounced migration and can cover a 300 to $600 \mathrm{~m}$ depth range each day, while others are shortdistance migrants (<150 m) (Brinton 1979, Sameoto et al. 1987). When migrating euphausiids enter deep waters, under some circumstances this also means encountering hypoxia, e.g. in fjords with reduced bottom water exchange (Onsrud \& Kaardvedt 1998, van

\footnotetext{
- Addressee for correspondence.

E-mail: j.stromberg@kmf.gu.se
}

den Thillart et al. 1999) or in the open ocean, where at depths of 400 to $1000 \mathrm{~m}$ there can be an $\mathrm{O}_{2}$ minimum layer (Sewell \& Fage 1948, Wyrtki 1962, Kamykowski \& Zentara 1990, Wishner et al. 1990). The physiological responses of krill, and other zooplankton, to hypoxia (mainly as a result of invading or inhabiting the $\mathrm{O}_{2}$ minimum layer) have recently been reviewed (Childress 1995, Childress \& Seibel 1998). Generally speaking, those responses consist of an increased efficiency of $\mathrm{O}_{2}$ extraction from the water, even at very low $p \mathrm{O}_{2} \mathrm{~s}$. Maintenance of aerobic metabolism is paramount. Those planktonic species that periodically invade waters where the $p \mathrm{O}_{2}$ is lower than the critical tension at which their ability to maintain aerobic metabolism fails invariably display a pronounced anaerobic capability, e.g. the crab Pleuroncodes planipes (Childress 
1975) and the copepod Gaussia princeps (Childress 1977). Presumably this could also be the case for some species of krill (e.g. Teal \& Carey 1967a) although there is as yet no information on their anaerobic capacity either in the laboratory or in the field.

At the beginning of 1998 the Gullmarsfjord, on the west coast of Sweden, became markedly hypoxic after $2 \mathrm{yr}$ in which bottom water exchange failed. The $\mathrm{pO}_{2}$ close to the bottom at $110 \mathrm{~m}$ was very low $(0.5 \mathrm{kPa})$ and at $70 \mathrm{~m} \mathrm{pO} \mathrm{O}_{2}$ was only $6.1 \mathrm{kPa}$.

Three species of krill occur in the Gullmarsfjord beside the Kristineberg Marine Research Station (KMRS): Meganyctiphanes norvegica, Thysanoessa raschii and $T$. inermis. All 3 are migrators, normally being found in deep waters during daytime and shallow water at night (Mauchline 1980, Buchholz \& Boysen-Ennen 1988, Buchholz et al. 1995, Bergström \& Strömberg 1997). The sound scattering layer, comprised of mainly $M$. norvegica, was found between 65 and $85 \mathrm{~m}$ depth in the daytime. This means that during the day $M$. norvegica may invade hypoxic water where the $\mathrm{pO}_{2}$ is lower than that of its critical $\mathrm{O}_{2}$ tension for maintaining aerobic metabolism as measured in laboratory experiments (van den Thillart et al. 1999). Consequently we used the unusual hypoxic conditions prevailing in the Gullmarsfjord to conduct a 'natural experiment', to investigate the extent to which anaerobic metabolism is used by Nordic krill $M$. norvegica in the field. The field work was complemented by an examination of anaerobic capacity in the laboratory, under conditions of hypoxia and anoxia.

\section{MATERIALS AND METHODS}

Field study. Krill Meganyctiphanes norvegica were collected in the Gullmarsfjord (58 $19.9^{\prime} \mathrm{N}, 11^{\circ} 33.8^{\prime} \mathrm{E}$ ) on the Swedish west coast, at dusk (17:00 h) on 16 January 1998. Concentrations of krill were located using an echo sounder $\left(120 \mathrm{kHz}\right.$ Lowrance X-15 ${ }^{\mathrm{M}}$, transducer 8 degree) and then collected using an Isaacs-Kidd Midwater Trawl (mouth size $0.6 \mathrm{~m}^{2}$; haul duration = $10 \mathrm{~min}$ ) from 60 to $70 \mathrm{~m}$ depth. This represented individuals from the top of the krill swarm which extended down to a depth of $85 \mathrm{~m}$. Haemolymph was collected immediately from a large number of individuals (see below). Between 100 and 150 individuals from the same catch were then transferred to each of 3 cages (vol. $\cong 30 \mathrm{l}$, mesh size $=1 \mathrm{~mm}$ ). The cages were lowered to 3 depths: 40,70 and $90 \mathrm{~m}$ within 40 min of initial capture and then left overnight from 17:00 to 11:00 h the next day. When the cages were retrieved, mortality was noted and haemolymph was sampled from surviving individuals. Samples were returned to the laboratory on ice and the concentration of L-lactate in the haemolymph ([lactate $]_{\mathrm{HL}}$ ) measured as described below. Values for $\mathrm{pO}_{2}$, temperature, and the salinity at about $10 \mathrm{~m}$ interval, between 40 and $105 \mathrm{~m}$ depth, were obtained on the 19 January, from the same location, by the RV 'Arne Tiselius'. Oxygen concentration was measured using Winkler titration (SIS 1975).

Laboratory studies. Krill were collected, using identical methods and from the same location as described above, on a number of occasions (always during the day) during January 1998. They were returned to the laboratory at KMRS within $1 \mathrm{~h}$ of capture. Here they were maintained in a number of opaque fibre-glass tanks (vol. = $350 \mathrm{l}$ each). Each tank was covered to keep the krill in darkness and supplied with natural sea water, pumped into the station from nearby 'deep' water $\left(34 \mathrm{PSU}, 8^{\circ} \mathrm{C}\right.$ ). Krill were not fed in the laboratory. Only large males and females (non-ovigerous) were used in the laboratory experiments. All experiments were performed within 1 to $2 \mathrm{~d}$ of collection.

The effect of acutely declining $\mathrm{pO}_{2}$ s on the initiation of anaerobic metabolism was examined as follows. A glass aquarium (vol. $=50 \mathrm{l}$ ) was filled with running ('deep') sea water and established in a controlled temperature environment. The $\mathrm{pO}_{2}$ of the water supplying the aquarium was altered by equilibrating it with a desired gas mixture, produced by controlled bubbling of $\mathrm{N}_{2}$ gas. The desired $\mathrm{pO}_{2}$ was maintained using a computer controlled system (LabVIEW ${ }^{\circledR} 2.2$ for Macintosh computers) employing feedback from an $\mathrm{O}_{2}$ sensor (Microprocessor OXI 196) within the equilibration chamber. The efficacy of this method was checked by independently measuring $\mathrm{pO}_{2}$ using a hand-held $\mathrm{O}_{2}$ probe coupled to an $\mathrm{O}_{2}$ meter (YSI). The $\mathrm{pH}$ of the sea water was measured at regular intervals using a $\mathrm{pH}$ electrode and probe (Mettler M90 Checkmate) in order to monitor any fluctuations that may have resulted from displacing $\mathrm{CO}_{2}$ as a result of $\mathrm{N}_{2}$ bubbling. To minimize the water/air interface, and thereby prevent $\mathrm{O}_{2}$ diffusion back into the sea water, a number of polystyrene sheets, cut to fit the aquaria, were floated on the water surface. To begin the experiment, the $p \mathrm{O}_{2}$ was reduced to $16 \mathrm{kPa}$. As soon as this $p \mathrm{O}_{2}$ was observed to be stable, 300 individual krill were gently introduced into the aquaria using a hand-held net. Immediately approximately 30 individuals were removed, using the same hand-held net and their haemolymph extracted (within 5 to $30 \mathrm{~s}$ of each one being removed from the aquaria) as described below. Thereafter $\mathrm{pO}_{2}$ was reduced to $2.5 \mathrm{kPa}$ in steps of 1 to $2 \mathrm{kPa}$, a process which lasted in total about $2 \mathrm{~h}_{\text {; }}$ at each step a further 30 individuals were removed and their haemolymph sampled.

To examine the effect of exposure to sustained hypoxia, at the level experienced by krill during the day $\left(p \mathrm{O}_{2}=\right.$ approximately $\left.6 \mathrm{kPa}\right)$, the following exper- 
iment was carried out: 2 glass aquaria, identical to those used in the previous experiment, were supplied with running 'deep' sea water. The $\mathrm{pO}_{2}$ in one of the aquaria was reduced to $6 \mathrm{kPa}$ over a period of about an hour. After the $p \mathrm{O}_{2}$ had stabilized in the experimental aquarium, both aquaria were supplied with approximately 150 individual krill as described before. Thereafter approximately 50 individuals were removed from each aquarium 3, 6 and $15 \mathrm{~h}$ after krill had been added and haemolymph sampled.

To examine the maximum rate of L-lactate accumulation in the haemolymph (as a measure of maximum rate of anaerobic metabolism), and also to serve as a control for handling and sampling stress, the following experiment was carried out: again 2 aquaria were prepared exactly as before except that in one of them the $\mathrm{pO}_{2}$ was reduced to $<0.1 \mathrm{kPa}$ (anoxia). Then 150 individual krill were introduced into each aquarium. Immediately upon introduction of the krill into the experimental set-up, individuals were removed and their haemolymph sampled at intervals of approximately $3 \mathrm{~min}$. This continued until there were no live krill remaining in the tank supplied with anoxic water.

Haemolymph sampling. After removal from the water, individual krill were quickly and gently blotted dry using tissue paper. Haemolymph (vol. $=0.5$ to $8.0 \mu \mathrm{l}$ ) was extracted from individuals using a 25 (or 50) $\mu l$ microsyringe (Hamilton), the needle of which was inserted dorsally, puncturing the arthrodial membrane which joins the abdomen to the carapace, directly into the pericardium. The haemolymph sample was then immediately transferred to a microcentrifuge tube (Eppendorf) kept on ice. Necessary samples were pooled until a minimum of $7 \mu \mathrm{l}$ was obtained. Then the tube was capped and kept at 0 to $4^{\circ} \mathrm{C}$ until used in any analysis.

Measurement of organic acids. The concentrations and relative proportions of organic acids present in pooled haemolymph samples collected from both control ( $\mathrm{n}=4$ pooled samples) and hypoxia stressed individuals ( $\mathrm{n}=5$ pooled samples) were estimated using a high-performance liquid-chromatography (HPLC) system (Gilson, France) coupled to an organic acid analysis column (Bio-Rad Aminex HPX-87H, $300 \times 7.8 \mathrm{~mm}$ ). Pooled haemolymph samples (vol. $=50 \mu l)$ were deproteinized by the addition of an equal volume of perchloric acid ( $600 \mathrm{mmol}^{-1}$ ). The resultant solution was then centrifuged $(10 \mathrm{~min}, 10000 \times g)$ to remove precipitated proteins, and the supernatant was neutralized by the addition of $10 \mu \mathrm{l}$ of $\mathrm{K}_{2} \mathrm{CO}_{3}\left(2 \mathrm{~mol} \mathrm{l}^{-1}\right)$. The sample was then centrifuged again, exactly as before, to remove precipitated potassium perchlorate. The supernatant was decanted and $20 \mu$ subsamples were introduced into the column using a microsyringe (25 $\mu$ l, Hamilton). Elution of the column was with sulphuric acid $\left(25 \mathrm{mmol} \mathrm{l}^{-1}\right)$ at a rate of $1 \mathrm{ml} \mathrm{min} \mathrm{m}^{-1}$. All of the organic acids of interest were eluted within an 18 min period and detected by a spectrophotometer $(\lambda=210 \mathrm{~nm})$. The following standards were run: acetate, fumarate, lactate, malate, pyruvate and succinate. As L-lactate appeared to be the major end-product of anaerobic metabolism in this species, only the concentration of this metabolite was measured in the remaining haemolymph samples using the method of Gutmann \& Wahlefeld (1974).

\section{RESULTS}

\section{Field study}

The $\mathrm{pO}_{2}$ in the water column near the krill collection and caging site exhibited a dramatic decrease with depth, which was pronounced between 40 and $90 \mathrm{~m}$ where there was a decrease from 14 to $1.8 \mathrm{kPa}$, equivalent to a change in concentration from 4.76 to $0.59 \mathrm{ml}$ $\mathrm{O}_{2} \mathrm{l}^{-1}$ (Fig. 1). At a depth of $105 \mathrm{~m}, \mathrm{OO}_{2}=1.2 \mathrm{kPa}$ (equivalent to $0.40 \mathrm{ml} \mathrm{O}_{2} \mathrm{l}^{-1}$ ). Temperature also declined with depth but only by about $2^{\circ} \mathrm{C}$ over the depth range 50 to $105 \mathrm{~m}$. Salinity remained almost constant at 33.68 to 34.17 PSU.

The [lactate] $]_{\mathrm{HL}}$ was greater in krill caged at $70 \mathrm{~m}$ $\left(\mathrm{pO}_{2}=6.1 \mathrm{kPa}\right)$ compared with those caged at $40 \mathrm{~m}$ $\left(\mathrm{pO}_{2}=14.9 \mathrm{kPa}\right)$ over an $18 \mathrm{~h}$ period $(t=2.2, \mathrm{n}=8, \mathrm{p}<$ 0.01 ) (Table 1). Mortality was considerably greater at $70 \mathrm{~m}$ than at $40 \mathrm{~m}$. No krill survived being caged at a depth of $90 \mathrm{~m}\left(p \mathrm{O}_{2}=1.8 \mathrm{kPa}\right)$ for $18 \mathrm{~h}$ and so we do not have values for [lactate $]_{H L}$ for this treatment. The [lactate $l_{H L}$ in krill trawled at dusk, just before they would

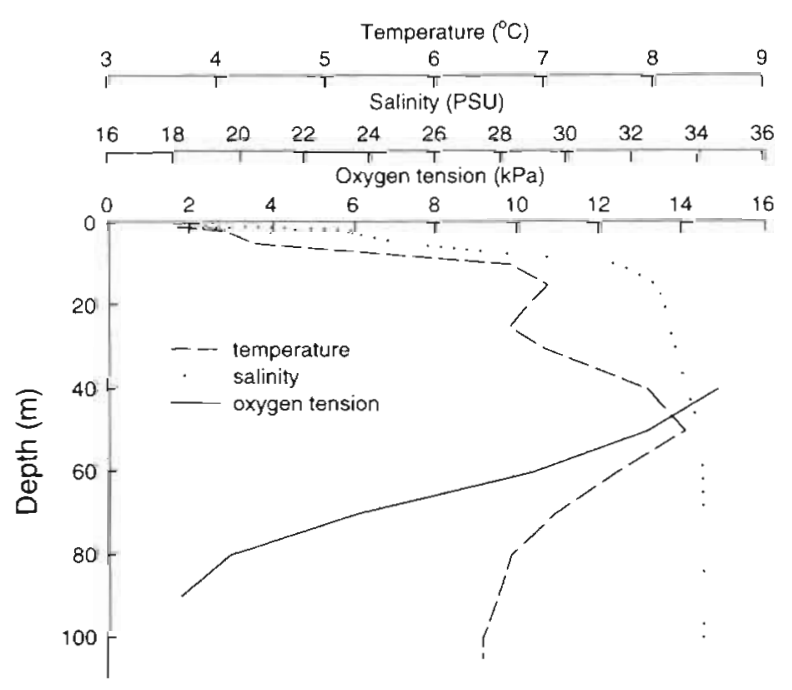

Fig. 1. Temperature, salinity and oxygen tension at the study site in the Gullmarsfjord on the west coast of Sweden, 19 January 1998 
Table 1 . Concentration of L-lactate in pooled haemolymph samples (means \pm 1 SD) of krill trawled from $60 \mathrm{~m}$ at dusk on 16 January 1998 and from individuals also caught at this time but subsequently caged for $18 \mathrm{~h}$ at 3 different depths. Also given is the mortality observed in each cage as no. of dead individuals (as percentage of total in parentheses)

\begin{tabular}{|lcccc|}
\hline $\begin{array}{l}\text { Sample } \\
\text { (depth, m) }\end{array}$ & $\begin{array}{c}\text { No. of } \\
\text { individuals } \\
\text { caged }\end{array}$ & $\begin{array}{c}\text { Mortality } \\
(\%)\end{array}$ & $\begin{array}{c}{[\text { lactate }]_{\mathrm{HL}}} \\
(\mathrm{mmol} \mathrm{I})\end{array}$ & $\begin{array}{c}\text { No. of pooled } \\
\text { haemolymph } \\
\text { samples examined }\end{array}$ \\
\hline $\begin{array}{l}\text { Newly trawled }(60) \\
\text { Caged }(40)\end{array}$ & 143 & $10(7)$ & $3.04 \pm 1.05$ & 8 \\
Caged (70) & 151 & $106(70)$ & $9.91 \pm 1.68$ & 8 \\
Caged (90) & 100 & $100(100)$ & - & - \\
\hline
\end{tabular}

there was a dramatic increase in [lactate $]_{H L}$, with concentrations steadily increasing with further decrease in $p \mathrm{O}_{2}$. When krill were maintained at a constant $\mathrm{pO}_{2}=6.3 \mathrm{kPa}$ (at, or just above, the critical $p \mathrm{O}_{2}$ determined above), for $15 \mathrm{~h}$ in the laboratory, there was a progressive increase in [lactate $]_{\mathrm{HL}}$ with time (Fig. 3). There were significant differences among the treatment groups (ANOVA, $F=$ 13.1, $\mathrm{n}=4$ to $8, \mathrm{p}<0.01$ ). According to a Student-Newman-Keuls test, the $15 \mathrm{~h}$ treatment was significantly different from the other treatments (3

vertically migrate and leave the hypoxic water mass where they had spent the day, from a depth of 60 to $70 \mathrm{~m}$, was closer to that of krill caged at $70 \mathrm{~m}$ than it was in those caged at $40 \mathrm{~m}$ (Table 1). Analysis of haemolymph samples from freshly trawled krill, and individuals caged at 40 and $70 \mathrm{~m}$ depth $(n=3$ in each case), using HPLC, indicated that L-lactate was the main end-product of anaerobic metabolism in this species. No other organic acids could be detected using our equipment in any of the haemolymph samples examined. Consequently, in the laboratory studies only L-lactate was measured as an indicator of anaerobic metabolism.

\section{Laboratory studies}

In krill exposed to acutely declining $\mathrm{pO}_{2}$, [lactate $]_{\mathrm{HL}}$ was relatively low and did not change over a wide range of $\mathrm{pO}_{2} \mathrm{~S}$ (Fig. 2); the average [lactate $]_{\mathrm{HL}}$ was $2.2 \mathrm{mmol} \mathrm{I}^{-1}$. However, at and below $\mathrm{pO}_{2}=4$ to $5 \mathrm{kPa}$

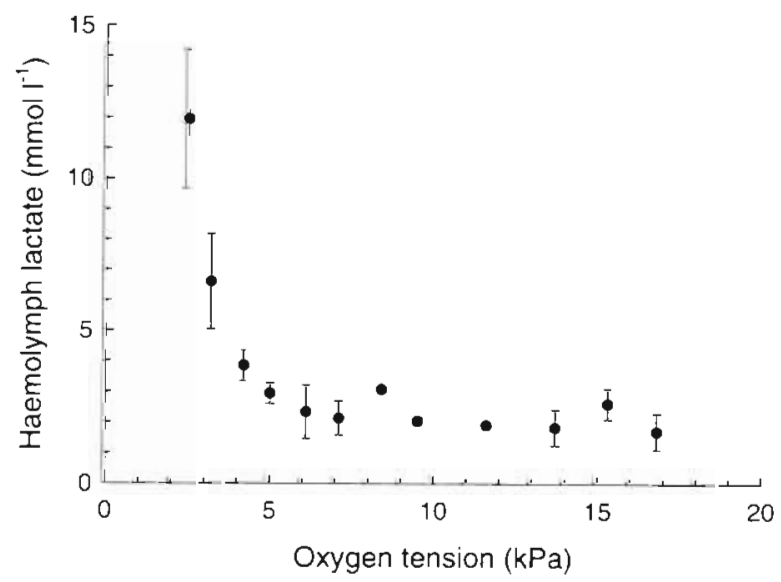

Fig. 2. Effect of acutely declining $\mathrm{pO}_{2} \mathrm{~s}$ of the concentration of L-lactate in the haemolymph of krill Meganyctiphanes norvegica. Values are means $\pm \mathrm{SE}, \mathrm{n}=3$ and $6 \mathrm{~h}), \mathrm{p}<0.05$. There was, however, no significant difference in the control (normoxic) treatment with time (mean [lactate $]_{\mathrm{IL}}=2.03 \mathrm{mmol}^{-1}, \mathrm{n}=15$ ).

When exposed to anoxia no krill survived for more than $1 \mathrm{~h}$. There was a pronounced increase in [lactate $]_{H L}$ as a result of exposure to anoxia (Fig, 4). Regression analysis indicated that there was a significant relationship between [lactate] $]_{H L}$ and exposure time $\left(r^{2}=0.47, p<0.001, n=21\right)$. Corresponding values for control individuals were $r^{2}=0.25, p=0.046, n=16$, where the average [lactate] HL $_{\text {was }} 4.3 \mathrm{mmol} \mathrm{I}^{-1}$. L-lactate accumulation was calculated as the slope of the line fitted to data for [lactate $_{\mathrm{Hi}}$ for each of the time intervals and was approximately $25 \mathrm{mmol}$ L-lactate haemolymph $\mathrm{l}^{-1} \mathrm{~h}^{-1}$.

\section{DISCUSSION}

L-lactate is the main metabolic end-product of anaerobic metabolism in Nordic krill Meganyctiphanes norvegica. This finding is in agreement with studies of many other crustacean species (Teal \& Carey 1967b,

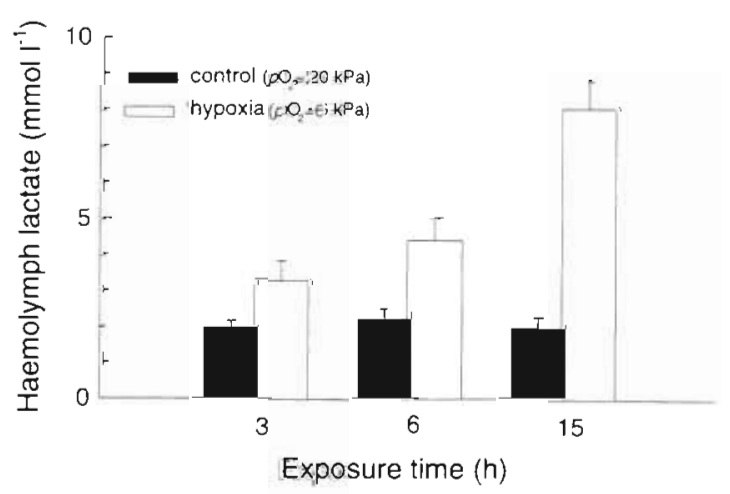

Fig. 3. Effect of maintaining krill Meganyctiphanes norvegica under constant hypoxic conditions on the concentration of Llactate in the haemolymph. Values are means $+\mathrm{SE}, \mathrm{n}=3$ 


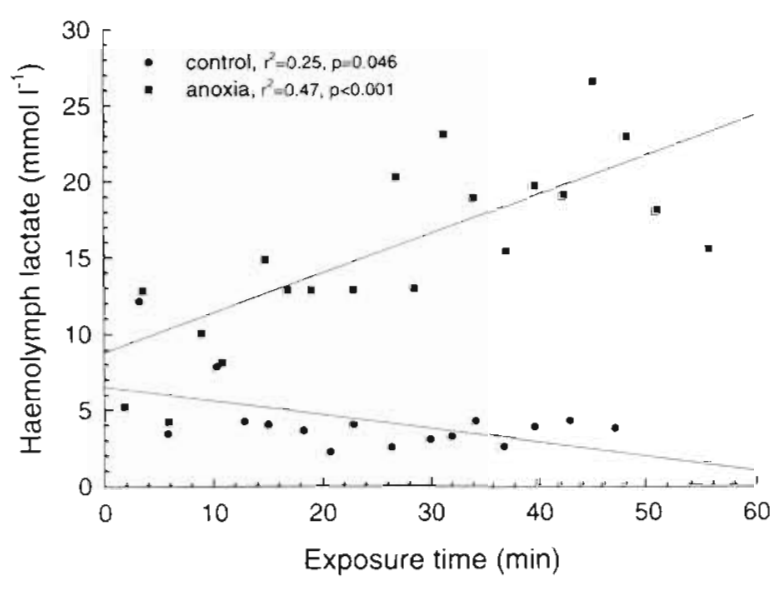

Fig. 4. Changes in the concentrations of L-lactate in the haemolymph of krill Meganyctiphanes norvegica with time under conditions of anoxia and normoxia (control). Lines fitted to data obtained using the method of least squares

Pritchard \& Eddy 1979, Bridges \& Brand 1980, Gäde 1984, Hagerman \& Szaniawska 1986, Taylor \& Spicer 1987, van Aardt 1988, Hill et al. 1991a,b, Anderson et al. 1994, Hagerman \& Vismann 1995, Nielsen \& Hagerman 1998). Although other minor end-products, such as alanine and succinate, have been detected in some species (de Zwaan \& Skjoldal 1979, Zebe 1982, Gäde 1984, Albert \& Ellington 1985, Hagerman \& Szaniawska 1990, Hervant et al. 1995) this was not the case here at least with regard to the organic acids (but not alanine) detectable by the system we used. The anaerobic capacity that does exist is usually not very well developed as many crustaceans (natant decapods in particular) show an anoxic tolerance ranging from a few hours (Packard 1905, Levin 1933, Tinson \& Laybourn-Parry 1985, Agnew \& Jones 1986, Hagerman \& Szaniawska 1986, Taylor \& Spicer 1987, Stickle et al. 1989, Hagerman \& Vismann 1995) to, more exceptionally, a few days (de Zwaan \& Skjoldal 1979, Zebe 1982, Hagerman \& Szaniawska 1990, Anderson et al. 1994, Hervant et al. 1995). The fact that $M$. norvegica did not survive more than an hour in anoxia makes it possibly the most anoxia sensitive crustacean species examined to date, even more than the natant decapods. Assuming that the rate of L-lactate accumulation in the haemolymph can be used as a measure of the rate of anaerobic metabolism (cf. Hill et al. 1991a), $M$. norvegica possesses a considerably greater rate of anaerobic metabolism than other crustaceans for which there are comparable data, e.g. Carcinus maenas (Hill et al. 1991a) and Palaemon elegans (Taylor \& Spicer 1987). If this were true, anoxia survival may be a function of both metabolic rate (during anoxia) and glycogen reserves available as an energy substrate (as found in other studies, e.g. Teal \& Carey 1967b, Taylor
\& Spicer 1987, Hill et al. 1991a, Anderson et al. 1994). Unfortunately, we were not able to measure whole body glycogen in this present study, although we predict that concentrations would be low.

Under conditions of acutely declining $\mathrm{pO}_{2} \mathrm{~s}$, [lactate $]_{\mathrm{HL}}$ in Meganyctiphanes norvegica did not change until a critical $\mathrm{pO}_{2}$ had been reached, ca 4 to $5 \mathrm{kPa}$. After this point 1 -lactate accumulation was both rapid and pronounced. However, during prolonged exposure $(15 \mathrm{~h})$ to a $p \mathrm{O}_{2}=6 \mathrm{kPa}$ in the laboratory, $M$. norvegica showed some accumulation of L-lactate in the haemolymph, although the rate was considerably lower than found under conditions of anoxia. Consequently, the critical $p_{2}$ at $8^{\circ} \mathrm{C}$ in this species probably lies between 4 and just above $6 \mathrm{kPa}$, the actual value dependent on the rate of $\mathrm{O}_{2}$ decline in the environment, the physiological condition of the individual and the duration of exposure and temperature. This critical $\mathrm{pO}_{2}$ agrees well with van den Thillart et al. (1999), who found that $M$. norvegica could regulate its rate of $\mathrm{O}_{2}$ uptake down to $30 \%$ of oxygen saturation $\left(p \mathrm{O}_{2}=\right.$ $6.3 \mathrm{kPa}$ ) in laboratory experiments. They also noted that substantial mortality occurred below this tension. This is interesting as Childress \& Seibel (1998) suggest that in planktonic animals, values for critical $\mathrm{pO}_{2} \mathrm{~s}<$ $4 \mathrm{kPa}$ are characteristic of specific adaptations to the reduced $\mathrm{pO}_{2} \mathrm{~s}$ encountered in the $\mathrm{O}_{2}$ minimum layer, while critical $\mathrm{pO}_{2} \mathrm{~s} \geq 4 \mathrm{kPa}$ are typical of midwater species living at high environmental $\mathrm{O}_{2}$ levels. Such a classification would place $M$. norvegica as a midwater species, with a respiratory physiology not as well developed for maintaining $\mathrm{O}_{2}$ uptake under hypoxia as that found in many inhabitants of the $\mathrm{O}_{2}$ minimum layer. This species also possesses a poorly developed anaerobic capacity and tolerance when its powers of regulation are exceeded. And yet, as we have seen, $M$. norvegica does migrate down into areas of pronounced hypoxia during the daytime (approximately 8 to $9 \mathrm{~h}$ at this time of year). Individuals trawled from a depth of 60 to $70 \mathrm{~m}$ had greatly elevated [lactate] $]_{\mathrm{HL}}$ when compared with control individuals in the laboratory or even krill caged at a depth of $40 \mathrm{~m}$ in the field. The possibility that such an elevated concentration is a result of functional anaerobiosis (i.e. swimming to escape the trawl and the subsequent stress of being in the net, removed and then sampled) cannot be totally discounted but it is unlikely as handling stress in the laboratory (particularly that encountered in the control group in the anoxia experiment) only resulted in slightly elevated levels. It is also unlikely that L-lactate accumulation in trawled individuals resulted from hypoxic exposure at a depth of $60 \mathrm{~m}$. Here the $\mathrm{pO}_{2}=10.5 \mathrm{kPa}$, which is in excess of the critical $\mathrm{pO}_{2}$ for this species. However, it should be noted that at $70 \mathrm{~m}$ depth the $\mathrm{pO}_{2}$ had declined to $6 \mathrm{kPa}$, a level which, in the laboratory, re- 
sulted in krill resorting to anaerobic metabolism. So the most likely explanation for elevated [lactate $]_{\mathrm{FL}}$ is that these krill were returning from much deeper, and hence more hypoxic, depths. At the time of trawling, krill were located at depths down to $85 \mathrm{~m}$, where the $p \mathrm{O}_{2}=2.5$ to $4.0 \mathrm{kPa}$, i.e. values below the critical $p \mathrm{O}_{2}$ of individuals of this population. Certainly krill could not survive prolonged exposure (albeit caged) at $70 \mathrm{~m}$ depth $\left(p \mathrm{O}_{2}=6.1 \mathrm{kPa}\right)$ and those that survived longest sustained a quite considerable $\mathrm{O}_{2}$ debt, in the form of accumulated L-lactate. Therefore we may conclude that krill can incur a significant $\mathrm{O}_{2}$ debt as a result of migrating, during the day, into hypoxic waters.

In conclusion, although Nordic krill Meganyctiphanes norvegica are not specifically adapted, either in terms of maintaining $\mathrm{O}_{2}$ uptake or their capacity for anaerobic metabolism, for inhabiting or invading hypoxic water masses, this does not seem to prevent them doing so. In the Gullmarsfjord, when lack of exchange of bottom water results in pronounced hypoxia in deep waters, $M$. norvegica still persist with their extensive diurnal migration, although this behaviour takes them into an environment for which, in terms of their respiratory physiology, they are not suited. Indeed it is very likely that they are near the limits of survival during the day. If this is so, the migration rhythm must be very strong and cannot be overridden by hypoxia, although there is some evidence that in some populations of $M$. norvegica the rhythm does cease under some circumstances (Bigelow 1926, Einarsson 1945, Cox 1975, Nicol 1984, 1986, Kaartvedt pers. comm.). What is clear is that the impetus to enter such hypoxic, and potentially lethal, environments during the day, e.g. to avoid predators, must be considerable.

More generally, although crustaceans as a group are not particularly good at coping with hypoxia, species that encounter hypoxia in their natural environment, e.g. species inhabiting intertidal rock pools (Palaemon elegans; Taylor \& Spicer 1987) or that create and inhabit burrows (thalassinids; Pritchard \& Eddy 1979. Anderson et al. 1994), seem to show some adaptation. The presently known geographical distribution of Meganyctiphanes norvegica (Mauchline 1980) indicates that this species rarely encounters hypoxia. In the North Atlantic, $\mathrm{O}_{2}$ minimum layers are infrequent and it is only in particular situations, such as fjords with poor bottom water exchange (e.g. Gullmarsfjord and Oslofjord) or in similar situations in more open waters (e.g. the Kattegat), that the Nordic krill are forced into semi-permanent hypoxic situations. Consequently it would be interesting to know if the respiratory physiology of $M$. norvegica in the Gullmarsfjord differs from that of individuals found in more oceanic environments and, if it does, the nature and source of the differences.
Acknowledgements. We wish to acknowledge the support for the stay of J.I.S. at the KMRS by Stiftelsen Olle Engkvist. Byggmästare. We are also grateful for the support of the Royal Swedish Academy of Sciences for the krill project (J.-O.S. and M.A.T.) and for the enthusiasm and help of the crews of the RVs 'Oscar von Sydow' and 'Arne Tiselius' Mr Sylve Robertsson's help with the construction of krill cages for the field experiment was invaluable as was the assistance of $\mathrm{Mr}$ Anders Klein and Mr Hans Olsson in operating the LabVIEW ${ }^{2}$. Our thanks also go to Mr Lennart Davidsson who helped with $\mathrm{CTD}$ recordings and $\mathrm{O}_{2}$ measurements on board the RV 'Arne Tiselius'

\section{LITERATURE CITED}

Agnew DJ, Jones MB (1986) Metabolic adaptations of Gammarus duebeni Liljeborg (Crustacea, Amphipoda) to hypoxia in a sewage treatment plant. Comp Biochem Physiol 84:475-478

Albert JL, Ellington WR (1985) Patterns of energy metabolism in the stone crab. Mcnippo mercenaria during severe hypoxia and subsequent recovery. J Exp Zool 234: $175-183$

Anderson SJ, Taylor AC, Atkinson RJA (1994) Anaerobic metabolism during anoxia in the burrowing shrimp Calocaris macandreae Bell (Crustacea: Thalassinidea). Comp Biochem Physiol 108A:515-522

Bergström B, Strömberg JO (1997) Behavioural differences in relation to pycnoclines during vertical migration of the euphausiids Meganyctiphanes norvegica (M. Sars) and Thysanoessa raschii (M. Sars). J Plankton Res 19:255-261

Bigelow HB (1926) Plankton of the offshore waters of the Gulf of Maine. Bull Bur Fish Wash 40(2):1-509

Bridges CR, Brand AR (1980) The effect of hypoxia on oxygen consumption and blood lactate levels of some marine Crustacea. Comp Biochem Physiol 65A:399-409

Brinton E (1979) Parameters relating to the distributions of planktonic organisms, especially Euphausiids in the eastern tropical Pacific. Prog Oceanogr 8:125-189

Buchholz F, Boysen-Ennen E (1988) Meganyctiphanes norvegica (Crustacea: Euphausiacea) in the Kattegat: studies on the horizontal distribution in relation to hydrography and zooplankton. Ophelia 29:71-82

Buchholz F, Buchholz C, Reppin J, Fischer J (1995) Diel vertical migrations of Meganyctiphanes norvegica in the Kattegat: comparison of net catches and measurements with acoustic Doppler current profilers. Helgol Meeresunters $49: 849-866$

Childress JJ (1975) The respiratory rates of midwater crustaceans as a function of depth occurrence and relation to the oxygen minimum layer off Southern California. Comp Biochem Physiol 50A:787-799

Childress JJ (1977) Effects of pressure, temperature and oxygen on the oxygen consumption rate of the midwater copepod Gaussia princeps. Mar Biol 39:19-24

Childress JJ (1995) Are there physiological and biochemical adaptations of metabolism in deep-sea animals? Trends Ecol Evol 10:30-36

Childress JJ, Seibel BA (1998) Life at stable low oxygen levels: adaptations of animals to oceanic oxygen minimum layers. J Exp Biol 201:1223-1232

Cox SJ (1975) Shore stranding of Meganyctiphanes norvegica (M. Sars). Estuar Coast Mar Sci 3:483-484

de Zwaan A, Skjoldal HR (1979) Anaerobic energy metabolism of the scavenging isopod Cirolana borealis (Lilljeborg). J Comp Physiol 129:327-331 
Einarsson H (1945) Euphausiacea, 1. Northern Atlantic species. Dana-Rep Carlsberg Found 27:1-191

Gäde G (1984) Effects of oxygen deprivation during anoxia and muscular work on the energy metabolism of the crayfish Orconectes limosus. Comp Biochem Physiol $77 \mathrm{~A}$ : 495-502

Gutmann I Wahlefeld AW (1974) L-lactate. Determination with lactate dehydrogenase and NAD. In: Bergmeyer HU (ed) Methods of enzymatic analysis, 2nd edn. Academic Press, New York, p 1464-1468

Hagerman L, Szaniawska A (1986) Behaviour, tolerance and anaerobic metabolism under hypoxia in the brackishwater shrimp Crangon crangon. Mar Ecol Prog Ser 34: $125-132$

Hagerman L, Szaniawska A (1990) Anaerobic metabolic strategy of the glacial relict isopod Saduria (Mesidotea) entomon. Mar Ecol Prog Ser 59:91-96

Hagerman L, Vismann B (1995) Anaerobic metabolism in the shrimp Crangon crangon exposed to hypoxia, anoxia and hydrogen sulfide. Mar Biol 123:235-240

Hervant F, Mathieu J, Garin D, Freminet A (1995) Behavioral, ventilatory, and metabolic responses to severe hypoxia and subsequent recovery of the hypogean Niphargus rhenorhodanensis and the epigean Gammarus fossarum (Crustacea: Amphipoda). Physiol Zool 68:223-244

Hill AD, Taylor AC, Strang RHC (1991a) Physiological and metabolic responses of the shore crab Carcinus maenas (L.) during environmental anoxia and subsequent recovery. J Exp Mar Biol Ecol 150:31-50

Hill AD, Taylor AC, Strang RHC (1991b) Radioisotope studies of the energy metabolism of the shore crab Carcinus maenas (L.) during environmental anoxia and recovery. J Exp Mar Biol Ecol 150:51-62

Kamykowski D, Zentara SJ (1990) Hypoxia in the world ocean as recorded in the historical data set. Deep-Sea Res 37: $1861-1874$

Levin BS (1933) Influence de quelques colorants vitaux sur l'asphyxie de divers animaux marins. C R Séance Soc Biol Fil 114:689-691

Mauchline J (1980) The biology of mysids and euphausids. In: Blaxter JHS, Russell FS, Yonge $M$ (eds) Advances in marine biology, Vol 18. Academic Press, London

Nicol S (1984) Population structure of daytime surface swarms of the euphausiid Meganyctiphanes norvegica in the Bay of Fundy. Mar Ecol Prog Ser 18:241-251

Nicol S (1986) Shape, size and density of daytime surfaces warms of the euphausiid Meganyctiphanes norvegica in the Bay of Fundy. J Plankton Res 8:29-39

Nielsen A, Hagerman L (1998) Effects of short-term hypoxia on metabolism and haemocyanin oxygen transport in the

Editorial responsibility: Otto Kinne (Editor),

Oldendorf/Luhe, Germany prawns Palaemon adspersus and Palaemonetes varians. Mar Ecol Prog Ser 167:177-183

Onsrud MSR, Kaartvedt S (1998) Diel vertical migration of the krill Meganyctiphanes norvegica in relation to physical environment, food and predators. Mar Ecol Prog Ser 171: $209-219$

Packard WH (1905) On the resistance to lack of oxygen and on a method of increasing this resistance. Am J Physiol 15: $30-41$

Pritchard AW, Eddy S (1979) Lactate formation in Callianassa californiensis and Upogebia pugettensis (Crustacea: Thalassinidea). Mar Biol 50:249-253

Sameoto DD, Guglielmo L, Lewis MK (1987) Day/night vertical distribution of euphausiids in the eastern tropical Pacific. Mar Biol 96:235-245

Sewell RBS, Fage L (1948) Minimum oxygen layer in the ocean. Nature 162:949-951

SIS (The Standardizing Committee of Sweden) (1975) Titrimetrisk bestämning av halten löst oxygen hos vatten. Swedish standard, SIS 028114:1-6

Stickle WB, Kapper MA, Liu LI, Gnaiger E, Wang SY (1989) Metabolic adaptations of several species of crustaceans and molluscs to hypoxia: tolerance and microcalorimetric studies. Biol Bull 177:303-312

Taylor AC, Spicer JI (1987) Metabolic responses of the prawns Palaemon elegans and P. serratus (Crustacea: Decapoda) to acute hypoxia and anoxia. Mar Biol 95:521-530

Teal JM, Carey FG (1967a) Respiration of a euphausiid from the oxygen minimum layer. Limnol Oceanogr 12:548-550

Teal JM, Carey FG (1967b) The metabolism of marsh crabs under conditions of reduced oxygen pressure. Physiol Zool 40:83-91

Tinson S, Laybourn-Parry J (1985) The behavioural responses and tolerance of freshwater benthic cyclopoid copepods to hypoxia and anoxia. Hydrobiologia 127:257-264

van Aardt WJ (1988) Lactate metabolism and glucose patterns in the river crab Potamonautes warreni Calman, during anoxia and subsequent recovery. Comp Biochem Physiol 91A:299-304

van den Thillart G, George RY, Strömberg JO (1999) Hypoxia sensitivity and respiration of Meganyctiphanes norvegica from Gullmarn Fjord, Sweden. Sarsia 84:105-109

Wishner K, Levin L, Gowing M, Mullineaux L (1990) Involvement of the oxygen minimum in benthic zonation on a deep seamount. Nature 346:57-59

Wyrtki K (1962) The oxygen minima in relation to ocean circulation. Deep-Sea Res 9:11-23

Zebe E (1982) Anaerobic metabolisn in Upogebia pugettensis and Callianassa californiensis (Crustacea, Thalassinidea). Comp Biochem Physiol 72B:613-617

Submitted: November 5, 1998; Accepted: March 19, 1999 Proofs received from author(s): July 26, 1999 